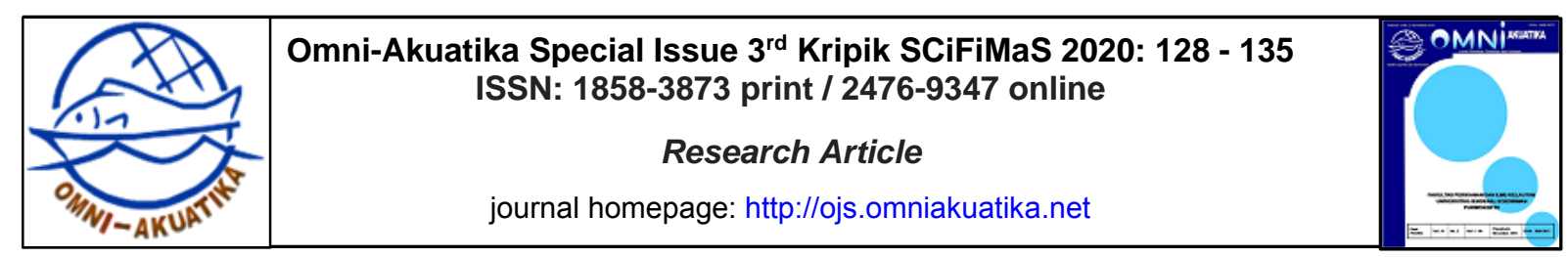

\title{
Organic Feed Enrichment Effects toward Growth Performance and Egg Production of Oithona similis
}

\author{
Diana Chilmawati ${ }^{*}$, Johannes Hutabarat ${ }^{1}$, Sutrisno Anggoro $^{2}$ and Suminto Suminto ${ }^{1}$ \\ ${ }^{1}$ Department of Aquaculture, Faculty of Fisheries and Marine Science, Diponegoro University, JIn. Prof Soedarto, SH, \\ Tembalang, Semarang 50275 Indonesia \\ ${ }^{2}$ Department of Aquatic Resources Management, Faculty of Fisheries and Marine Science, Diponegoro University, JIn. \\ Prof Soedarto, SH, Tembalang, Semarang 50275 Indonesia \\ *Corresponding author: dianachilmawati@yahoo.com
}

Received 20 November 2019; Accepted 1 October 2020; Available online 31 December 2020

\begin{abstract}
The optimum condition of culture media and feed diets which fit the necessities of Oithona similis life (ecophysiological) is very important for it to grow and develop in its maximum. The enrichment of $O$. similis feed can be done by adding fermented organic feed. Providing organic feed with optimum protein content is necessary to support the growth process and reproduction of $O$. similis. Osmoregulation process of water organism which is influenced by media salinity is related to bioenergetics process as the effort to use feed energy for the growth. This research aimed to examine the effect of different organic feed protein content and to determine the optimum point which may result in the best growth and egg production of $O$. similis in the optimum condition of culture media. The study used an experimental method with a completely random design consisting of 4 treatments and 4 repetitions each, i.e. O. similis culture with A. $25 \%$; B. 30\%; C. $35 \%$; and D. $40 \%$ organic feed protein content. The results showed that the difference of protein content in organic feed affects the growth and production of $O$. similis eggs. The optimum point of protein content in the fermented organic feed is on protein content $\mathrm{B}$, i.e. $30 \%$, which resulted in the best growth performance (70.44 \pm 0.43 ind $\mathrm{mL}^{-1}$ total density, $0.213 \pm 0.001$. day ${ }^{-1}$ population growth rate, and $27.38 \pm 0.48$ eggs. $^{-}$ind $^{-}$ 1 egg production. (ttujuan dan pembahasan harus past tense), Tujuan di abstrak minimal harus menggambarkan atau sama denga tujuan di pendahuluan)
\end{abstract}

Keywords: enrichment, Oithona similis, organic feed, protein, reproduction.

\begin{abstract}
ABSTRAK
Kondisi optimum media kultur dan diet pakan yang sesuai dengan kebutuhan hidup (ekofisiologis) Oithona similis sangat penting agar dapat tumbuh dan berkembang secara maksimum. Pengkayaan pakan terhadap 0 . similis dapat dilakukan dengan penambahan pakan organik yang difermentasi. Kandungan protein pakan organik yang optimum sangat diperlukan untuk mendukung proses pertumbuhan dan reproduksi $O$. similis. Proses bioenergetika dalam upaya pemanfaatan energi pakan untuk pertumbuhan, erat hubungannya dengan proses osmoregulasi organisme air yang dipengaruhi oleh salinitas media kulturnya. Tujuan penelitian ini adalah mengkaji pengaruh perbedaan kandungan protein pakan organik dan menentukan titik optimum yang memberikan performa pertumbuhan dan produksi telur 0 . similis terbaik pada kondisi salinitas media kultur yang optimum. Penelitian ini menggunakan metode eksperimental dengan Rancangan Acak Lengkap yang terdiri dari 4 perlakuan dengan masing-masing 4 kali ulangan, yaitu: kultur O. similis dengan kandungan protein pakan organik A. 25\%; B. 30\%; C. 35\%; dan D. $40 \%$. Hasil penelitian menunjukkan bahwa perbedaan kandungan protein pada pakan organik berpengaruh terhadap pertumbuhan dan produksi telur $O$. similis. Titik optimum kandungan protein pada pakan organik yang difermentasi adalah pada kandungan protein $30 \%$, yang memberikan performa pertumbuhan (kepadatan total $70,44 \pm 0,43$ ind./ml, laju pertumbuhan populasi $0,213 \pm 0,001 /$ hari), produksi telur $(27,38 \pm 0,48$ telur/ind $)$ terbaik.
\end{abstract}

Kata kunci: pengkayaan, Oithona similis, pakan organik, protein, reproduksi. 


\section{Introduction}

Copepods of Oithona sp. is one of the zooplankton natural feed types which can be utilized as feed for larvae stadia in fish and shrimp hatchery (Molejon and Alvarez-Lajonchere, 2003). Copepod in marine waters ecosystem is categorized as a significant part of the food web and food chain in trophic levels in the sea (Sampey et al., 2007; Drillet et al., 2011). Copepods play a role as the first consumer in food chains at sea for the first producers of phytoplankton cells (Perumal et al., 2009). The population of copepods is mainly influenced by its surrounding biotic conditions such as the availability of natural feed sources and phytoplankton cells (Noyon and Froneman, 2013), predators and competitors of copepods and other types of zooplankton, and certainly its biological environmental conditions like temperature, salinity, and dissolved oxygen (Beyrend-Dur et al., 2011).

The optimum condition of the culture media and feed diet containing protein which matches Oithona sp. life needs (ecophysiological) is fundamentally important for its maximum growth. Microalgae diets that contain nutrition needed by Oithona sp. is essentially decisive for successful Oithona sp. culture (Chilmawati and Suminto, 2016). One of various inputs in the natural feed cultivation system is enrichment of which the composition must be carefully concerned. This is due to the fact that it will cause nutritional deficiencies or even the excess of dangerous substances if the composition is not properly correct (Chilmawati and Suminto, 2010). Feed enrichment by giving the best microalgae and adding fermented organic feed is proven to improve the growth and egg production performance of Oithona sp. (Suminto et al., 2018).

Protein is main biochemical component besides fats and carbohydrates in metabolic process of copepods (Santhanam and Perumal, $2012^{b}$ ). Thus, protein content in feed affects copepods' growth and egg production (Holmborn and Elena, 2008). Furthermore, protein content functions as fuel used for RNA/DNA ratio in Copepod growth. Meanwhile, DNA is a factor related to molting process and RNA has an important role in protein synthesis. This is a complex process in metabolism involving the interaction of nucleic acids and proteins (Yebra et al., 2011). It has been studied that growth is correlated with protein content in the consumed feed (Gorochova, 2003; Gorokhova et al., 2007).
Protein content in feeding should possess similar nutritional profile with the phytoplankton (Wang et al., 2014).

The studies concerning organic feed with optimum protein content for Oithona sp. has not been found until recently. Therefore it is necessary to conduct a research focusing on feed enrichment using microalgae diet and fermented organic feed with different protein contents, which provides the best growth and egg production of $O$. similis in the optimum condition of culture media. This research aimed to examine the effect of different organic feed protein content and to determine the optimum point which may result in the best growth and egg production of $O$. similis in the optimum condition of culture media.

\section{Materials and Methods}

\subsection{Study area}

This research was conducted at the Coastal Area Development Laboratory, Faculty of Fisheries and Marine Science, Diponegoro University, Jepara Campus, Central Java, Indonesia from July to September 2018.

\subsection{Preparation of phytoplankton culture and} fermented organic feed.

This study used Chaetoceros calcitrans as the best phytoplankton feed for Oithona sp. (Chilmawati and Suminto, 2016a). This C. calcitrans was obtained from live feed laboratory of Brackish Water Culture Development Center (local term: Balai Besar Pengembangan Budidaya Air Payau or BBPBAP) located in Jepara, Central Java, Indonesia. This phytoplankton was cultured using seawater which has been sterilized at $25-28^{\circ} \mathrm{C}$ temperature, with 28-30 ppt salinity, and $\mathrm{pH}$ 8-9. The sterilized seawater was then added by a solution of sodium hypochlorite $(\mathrm{NaClO})$ at a dose of $60 \mathrm{mg} \cdot \mathrm{L}^{-1}$ for $10-30$ minutes. Moreover, it was added with a solution of $80 \mathrm{mg} \cdot \mathrm{L}^{-1}$ sodium thiosulphate $\left(\mathrm{NaS}_{2} \mathrm{O}_{3}\right)$ for the process of dechlorination for 24 hours using aeration The culture was done in a $60 \mathrm{~L}$ volume size plastic tube, which has been filled by $40 \mathrm{~L}$ of sterile seawater. The culture used a modified Walne media at a dose of $0.5 \mathrm{ml} . \mathrm{L}^{-1}$ in 24 hours photoperiod light and 1500-1800 Lux light intensity. Besides, culture media also used aeration. The inoculation volume of $C$. calcitrans is $10 \%$ of the culture media volume (Lee et al., 2006). 
The peak of $C$. calcitrans cell growth is commonly on day 6 . In addition, C. calcitrans culture can be harvested when it reaches the exponential phase because it at this point contains the highest nutrients (Creswell, 2010). The density of $\mathrm{C}$. calcitrans cell is calculated daily by taking its cell samples under a microscope (Olympus $\mathrm{CH} 20$ ) and using 10x magnification with a hemocytometer (brand: Neubauer with $0.0025 \mathrm{~mm}^{3}$ volume).

Organic feed fermentation was done by using a combination of materials in the form of organic flour consisting of tofu, rice bran, and fish flour to make powder feed with average diameter of 50-100 $\mu \mathrm{m}$ (Suminto et al., 2018). The plastic tube was filled with $10 \mathrm{~mL}$ EM4 of probiotics containing Lactobacillus casei, Saccharomyces cerevisiae, and Bacillus sp. Then, the mixture is filled with $200 \mathrm{~mL}$ of purified water and $25 \mathrm{~mL}$ of molasses for $1 \mathrm{~kg}$ of mixed organic feed. The incubation was done for 48 hours before it is used.

\subsection{Culture condition of Oithona similis.}

Copepods were obtained from an axenic culture in the live food Laboratory of Marine Culture Development Research Center (MCDRC) in Lampung, Indonesia. The copepods species used was Oithona similis as the findings of Chilmawati et al. (2019). O. similis culture was carried out in $250 \mathrm{~mL}$ of Erlenmeyer volume with $100 \mathrm{~mL}$ of sterile seawater,19.44 ppt optimum salinity (Chilmawati et al., 2019), at $27-28^{\circ} \mathrm{C}$ water temperature, $\mathrm{pH} 8$, and 1 ind. $\mathrm{mL}^{-1}$ from the initial density (Lee et al., 2006) for 20 days. The method used for feeding was libitum. The number of C. calcitrans given to $O$. similis was 0.01 mg.ind ${ }^{-1}$ (Lee et al., 2006). Based on Suminto et al. 's (2018) study, the dose of fermented organic feed is 0.5 g. $\mathrm{L}^{-1}$ culture medium with a combination of $50 \%$ phytoplankton cells and $50 \%$ organic fermentation feed (Chilmawati and Suminto, 2016; Suminto et al., 2019). The population of $O$. similis on Nauplii, Copepodite, and adult stages was observed under a microscope (Olympus CYK41). Each stage is determined by viewing its morphology (Takahashi and Uchiyama, 2007).

\subsection{Design of the experiment}

This study conducted a completely randomized design with 4 treatments and 4 repetition (replications). Treatment $A$ involved $O$. similis cultured with fermented organic feed containing $25 \%$ protein. Treatments B, C, and D were done by culturing $O$. similis with fermented organic feed containing $30 \%, 35 \%$, and $40 \%$ protein. Cell density of $O$. similis was calculated once every 4 days to obtain total population, growth performance, and egg production.

\subsection{Data collection and statistical analysis.}

The density of $O$. similis was counted once every 4 days during 20 days of observations. 30 $\mathrm{mL}$ of sub-sample was taken from the culture media to calculate the total number of $O$. similis, specific population growth rate $(r)$, and egg production.

Growth performance was calculated using Cheng et al. (2011) equation:

$$
r=\frac{\ln \mathrm{Nt}-\ln \mathrm{No}}{\mathrm{t}}
$$

Where $r$ is population growth $\left(\right.$. day $\left.^{-1}\right), \mathrm{Nt}$ is the final density of $O$. similis, $N_{0}$ is the initial density of $O$. similis and $t$ is days needed to achieve $\mathrm{O}$. Similis maximum growth.

Egg production is the average number of eggs produced by the female $O$. similis during their lifetime according to Zamora-Terol et al. (2014):

$$
\text { Egg production }=\frac{\sum s x e}{\sum n}
$$

Where $s$ is the amount of egg sac, e is the average amounts of egg per sac and $n$ is the number of ovigerous females (ind).

The data were then analyzed by One Way Analysis of Variance (ANOVA) to determine the effect of different protein content in organic feed on growth performance and egg production of $O$. similis. Least Significant Different (LSD) test $(\alpha=0.05)$ by using SPSS 16 was conducted when the treatment showed a significant effect.

\section{Results and Discussion}

\subsection{O. similis population}

Different protein content in organic feed significantly affects ( $p .<0.05)$ on the growth performance of $\mathrm{O}$. similis. Total density is the total number of naupli, copepodite and adult copepods, including adult copepods with eggs. According to the results of each $O$. similis stage on the last day of culture (day 20), it showed that the highest density was on the treatment of organic feed with $30 \%$ protein content (Figure 1). The observation results on day 20 indicated that $40 \%$ protein had the lowest density.

Based on the orthogonal polynomial test on Oithona similis culture density with different 


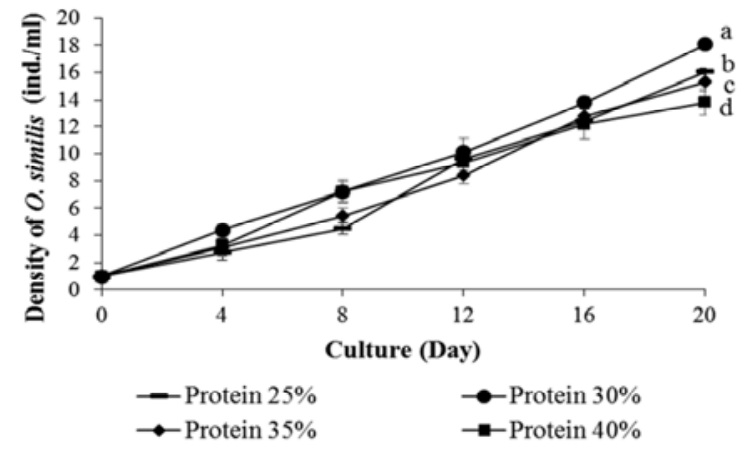

Figure 1 . The density of $O$. similis at different protein content during 20 days culture period. Values not sharing the same letter are different significantly from one another $(p<0.05)$ by Least Significant Difference Test

protein content, it obtained a cubic patterned relation (Figure 2 ) with a regression equation, i.e. $y=0,009 x^{3}-0,91 x^{2}+29,975 x-305.19$ and $R^{2}=$ 0.8919 and the optimum point of protein content was at $30 \%$. The $\mathrm{R}^{2}$ value indicated that $89.19 \%$ of $O$. similis total density was influenced by organic feed protein content while the remaining $10.81 \%$ was influenced by other factors.

\subsection{Specific growth rate of Oithona similis population}

The difference in protein content indicated a significant effect $(p<0.05)$ on the specific growth rate of $O$. similis population (Figure 3 ). The highest value of the population-specific growth

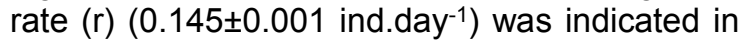
$O$. similis culture given with organic feed containing $30 \%$ protein. Organic feed containing $25 \%$ and $35 \%$ protein respectively resulted in R-

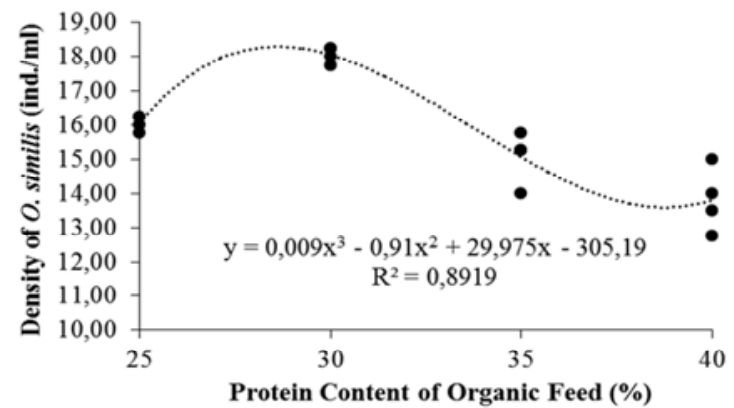

Figure 2. Relation model between protein content in organic feed and density of Oithona similis

value at $0.139 \pm 0.001$ and $0136 \pm 0.002$ ind.day ${ }^{-1}$. The lowest population-specific growth rate $\left(0.131 \pm 0.003\right.$ ind.day $\left.{ }^{-1}\right)$ was shown in culture of O. similis given with organic feed containing $40 \%$ protein.

The curve of $O$. similis population-specific growth rate during this study with protein content differences (Figure 4) indicated that there was a cubic patterned relation showed by equation $y=$ $3 \mathrm{E}-05 \mathrm{x}^{3}-0.0032 \mathrm{x}^{2}+0.1038 \mathrm{x}-0977$ with $\mathrm{R}^{2}=0.9557$. This described that $95.57 \%$ of the population-specific growth rate was influenced by protein content difference in organic feed and $4.43 \%$ was influenced by other factors. The optimum point was reached when providing organic feed containing $30 \%$ protein.

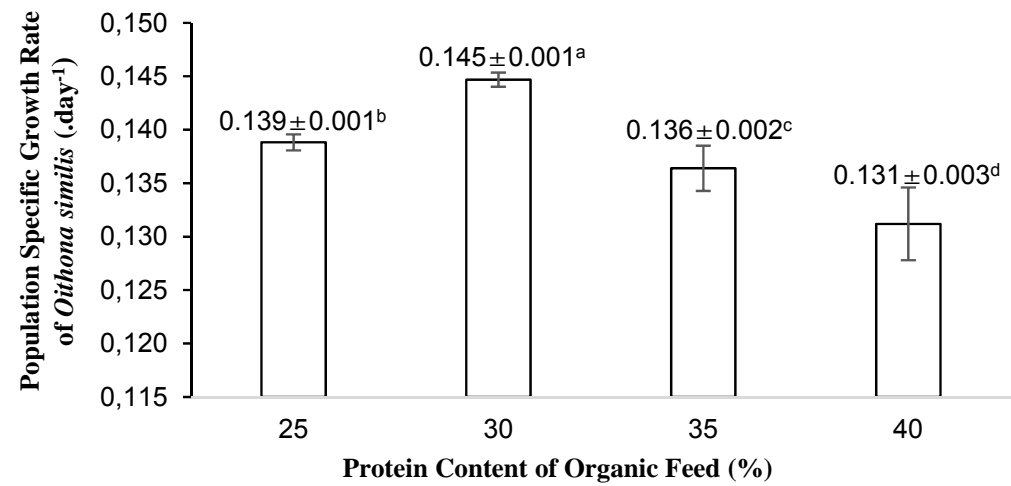

Figure 3. Spesific growth rate of $O$. similis population at different protein content during 20 day culture period. Values not sharing the same letter are different significantly from one another $(p<0.05)$ by Least Significant Difference Test 


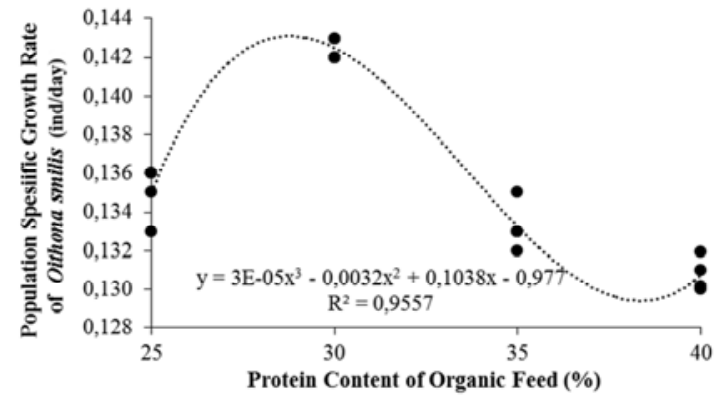

Figure 4. Correlation between protein content and the population specific growth rate of $O$. similis

\subsection{Egg production of $O$. similis.}

The histogram of $O$. similis average egg production at the end of the observation (Figure 5) showed that culture with $30 \%$ protein content led to the highest egg production $(26.75 \pm 0.96$ egg.ind $\left.{ }^{-1}\right)$ which was significantly different $(p$ $<0.05$ ) with all three other treatments. Moreover, giving organic feed containing $25 \%$ and $35 \%$ protein generated egg production which was not significantly different $(p>0.05)$ while $40 \%$ protein content resulted significantly different $(p>0.05)$ egg production $\left(20.50 \pm 0.58\right.$ egg.ind $\left.{ }^{-1}\right)$.

Based on the orthogonal polynomial test on egg production of $O$. similis fed by organic feed with different protein contents, it obtained a cubic patterned relation with the following equation $y=$ $0,0107 x^{3}-1,095 x^{2}+36,558 x-372.5$ and $R^{2}=$ 0.9244 and the optimum point was on protein content $30 \%$. The $\mathrm{R}^{2}$ value indicated that $92.44 \%$

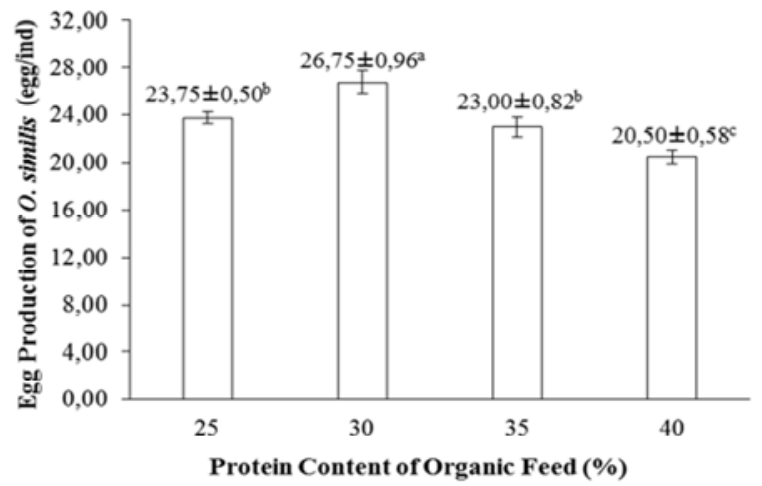

Figure 5. Egg production of $O$. similis at different protein content during 20 days culture period. Values not sharing the same letter are different significantly from one another $(p<0.05)$ by Least Significant Difference Test

of $O$. similis egg production was influenced by organic feed protein content while $7.56 \%$ of egg production is influenced by other factors.

The feeding of organic feed fermented with different protein contents and combined with the best microalgae diet has caused different influence on the growth performance and egg production of $O$. similis cultured at optimum media salinity. The feeding of organic feed in addition to phytoplankton cell feed has essential effect on the growth and egg production of Oithona sp. (Suminto et al., 2018). The increase in organic feed containing protein is presumed to highly improve the quality and quantity of Oithona similis. Protein is an important component for growth (Lee et al., 2006), population density (Drillet et al., 2011), and copepods fertility ((Rajthilak et al., 2014).

The use of organic material from mixture of

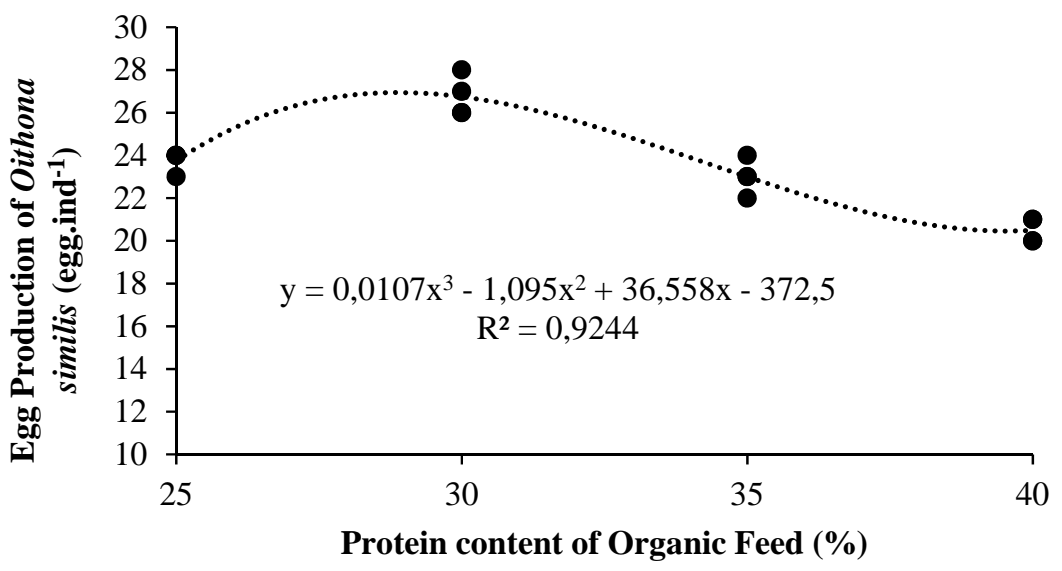

Figure 6. Correlation between protein content and egg production of $O$. similis 
fish flour, pulp tofu and fermented bran flour can improve the quality and quantity of the cultured $O$. similis. In addition, these waste and dirt materials are rich in organic materials and some types of microbes which can convert them into carbohydrates, proteins, pigments, oils, alcohol, aldehydes, and so on that can be used by copepods to increase its population. Previous study by Molejon and Alvarez (2003) mentioned that the use of fermented organic material can trigger the growth of Ciliata, bacteria, and detritus, and does not give any negative effect on copepods since these organisms are also food sources for copepods. Fermentation is a unique process which can improve nutritional value of feed material (Felix and Berindo, 2008). Fermentation on organic materials of feed nutrient sources can improve the growth of copepod (Rajhtilak et al., 2014). Fermentation also increases the availability of such vitamins as Riboflavin, Cyanocobalamin, thiamine, niacin, $\mathrm{B}_{6}$, $\mathrm{B}_{12}$, and folic acid levels in several feed material (Felix and Berindo, 2008). Some studies stated that the use of organic fermentation materials as copepod feed as one in Japan (Omori, 1973; Fukusho, 1980; Fukusho et al., 1980 in Molejon et al., 2013) could produce good result in culture. Organic feed containing $30 \%$ protein provided the best growth performance than those of the other three treatments. Thus, it was assumed that organic feed containing $30 \%$ protein fit with the needs of $O$. similis for its metabolic and growth processes. Santhanam and Perumal (2012) mentioned that protein is the main biochemical component of Oithona sp. and is the major fraction rather than lipid and carbohydrates which function as spare energy and metabolic substrate. The protein needs in each species depend on the type, size, feed material, quality of protein, and environment.

Giving organic feed with $25 \%$ protein content resulted in lower growth performance and egg production than that containing $30 \%$ protein. This was presumed that the protein content still could not meet the needs of $O$. similis to grow and reproduce. Protein is the main source of nutrients in the feed playing a significant role to form the materials for growth, producing enzymes, and other substances (Steffens, 1989). Robinson and $\mathrm{Li}$ (2007) also mentioned that protein will be continuously synthesized and degraded in the body of cultivars. In addition, food supply in the form of non-specific amino acids and nitrogen is needed during its life for body maintenance and growth. Thus, the growth and reproduction of $O$. similis will also not be able to achieve its maximum if the quantity and quality of feed are still inadequate.

This study also concerned Robinson and $\mathrm{Li}$ (2007) on several factors affecting feed protein requirements such as size, cultivars, water temperature, feeding, the amount of non-protein energy in the feed, the quality of protein, the availability of natural feed, and the practice of feed management. The results of this study showed that an increase of protein content in organic feed did not always increase the growth of $O$. similis. The use of limited volume and the absence of aeration on culture media was assumed to be the cause of growth performance and egg production of $O$. similis fed with organic feed containing $35 \%$ and $40 \%$ protein to be lower than those with $30 \%$ and $25 \%$ protein content. Thus, it is necessary to do a study concerning the influence of aeration and culture volume differences on the growth reproduction performance of $O$. similis.

The highest egg production was also produced by $O$. similis fed with organic feed containing with $30 \%$ protein. Moreover, high protein levels do not guarantee that egg production will also be high. It may be because the nutritional quality of organic feed fermentation is still insufficient eventhough it is much higher in quantity. This result is supported by (Peterson et al., 1991) stating that the low production of Oithona sp. can also be affected by the concentration of feed and the limited feed.

The difference in protein content in organic feed has significant effect on the growth and egg production of $O$. similis. Organic feed containing $30 \%$ protein and microalgae diet with Chaetoceros calcitrans resulted in the best growth performance $\left(18,06 \pm 0.24\right.$ ind. $\mathrm{mL}^{-1}$ total density, $0,145 \pm 0.001$. day $^{-1}$ population growth rate, and $26,75 \pm 0.96$ eggs.ind.$^{-1}$ egg production) in O. similis culture with optimum salinity (19.4 ppt). Based on the population growth rate and egg production of $\mathrm{O}$. Similis produced, the optimum point of protein content in O. Similis organic feed was on $30 \%$ protein content.

\section{Conclusions}

The difference of protein content in organic feed has a significant influence on the growth and egg production of $O$. similis in which the organic feed containing $30 \%$ protein content showed the best growth performance and egg production $\left(18.06 \pm 0.24\right.$ ind. $\mathrm{mL}^{-1}$ total density, $0.145 \pm 0.001$.day $^{-1}$ population growth rate, and $26.75 \pm 0.96$ eggs.ind ${ }^{-1}$ egg production). 
Furthermore, based on population-specific growth rate and egg production, the optimum protein content of organic feed for $O$. similis was $30 \%$.

\section{Acknowledgements}

This research was funded by Lembaga Pengelola Dana Pendidikan (LPDP) through Beasiswa Unggulan Dosen Indonesia Dalam Negeri (BUDI DN) program.

\section{References}

Beyrend-Dur, D., Kumar, R., Rao T.R., Souissi S., Cheng S.H., Hwang J.S. 2011. Demographic parameters of adults of Pseudodiaptomus annandalei (copepoda: calanoida): Temperature-salinity and generation effect. Journal of Experimental Marine Biology and Ecology 404: 1-14.

Cappuzo J. M. 1999. Crustacean bioenergetics : The role of environment variables and dietary levels of macronutrient on energetic eggiciencies. In G.D. Pruder et al., eds. Prociding Aquaculture Nutrition, Biochemical and Physiology Approach. Louisiana State University Baton Rouge.

Cheng S., Ka S., Kumar R., Kuo C.S., Hwang J.S. 2011. Effect of salinity, food level, and the presence of microcrustcean zooplankters on the population dynamics of rotifer Brancionus rotundiformis. Hydrobiologia 669: 289-299.

Chilmawati D., Suminto. 2016a . Optimalisasi kultur Oithona sp. melalui pemberian pakan organik yang difermentasi sebagai upaya pengganti artemia untuk peningkatan produksi hatchery larva udang vaname. Laporan Penelitian Hibah Bersaing, 64 p.

Chilmawati D., Suminto. 2016 . The effect of different diet of phytoplankton cells on growth performance of copepod, Oithona $\mathrm{sp}$. in semi-mass culture. Aquatic Procedia 7: 39-45.

Chilmawati D, Hutabarat J., Anggoro S., Suminto. 2019. Biomolecular identification and optimization of growth performance and egg production in Oithona sp. under different salinity culture. AACL Bioflux 12(2): 575585.

Creswell L. 2010. [Phytoplankton culture for aquaculture feed]. Southern Regional
Aquaculture Center, SRAC Publication No. 5004, 16 pp.

Drillet G., Frouel S., Sichlau M.H., Jepsen P.M., Hojgaard J.K., Joarder A.K., Hansen B.W. 2011. Status and recommendation on marine copepod cultivation for use as live feed. Aquaculture 315: 155-166.

Felix N., Brindo R.A.. 2008. Fermented feed ingredients as fish meal replacer in aquafeed production. Dept. of Aquaculture Fisheries College and Research Institute Tamilandu Vetenary and Animal Sciences, University India. Research and Farming Technique 31-33.

Fukusho K.. 1980. Mass production of a copepod, Tigriopus japonicus, in combination culture with a rotifer Brachionus plicatilis, fed-yeast as food source. Bulletin of the Japanese Society and Scientific Fisheries 46(5): 625629.

Fukusho K., Arakawa T., Watanabe T. 1980. Food value of a copepod, Tigriopus japonicus, cultured with n- yeast for larvae and juveniles of mud Dab Limanda Yokohamae. Bulletin of the Japanese Society and Scientific Fisheries 46(4): 499503.

Gorokhova E. 2003. Relationship between nucleic and level and egg production rates in Acartia bifilosa implications for growth assessment of copepods in situ. Marine Ecologi Progress Series 262: 163-172.

Gorokhova E., Anna E., Susanna H., Elena N.Z. 2007. Dynamic responses to phytoplankton blooms in the Northem Baltic proper. Marine Ecology Progress Series 349: 213-225.

Holmborn T., Elene G. 2008. Relationship between RNA content and egg production rate in Acartia bifilosa (Copepoda, Calanoida) of different spatial and temporal origin. Marine Biologi 153: 483-491.

Hutabarat J. 2005. [Pakan buatan ramah lingkungan (eco-friendly artificial feed)]. Bahan Ajar. Fisheries and Marine Science Faculty, Diponegoro University, Semarang, $10 \mathrm{pp}$. [in Indonesian]

Lee K. W., Park H.G., Lee S.M., Kang H.K. 2006. Effect of diets on the growth of the brackish water cyclopoid copoped Paracyclopina nana Smirnov. Aquaculture 256: 346-353.

Molejon O.G.H., Alvarez-Lajonchere L. 2003. 
Culture experiments with Oithona oculata Farran, 1913 (Copepoda: Cyclopoida), and it's advantages as food for marine fish larvae. Aquaculture 219: 471-483.

Noyon M., Froneman P.W. 2013 Variability in the egg production rates of the calanoid copepod, Pseudodiaptomus hessei in a South African Estuary in relation to environmental factors. Estuarine, Coastal and Shelf Science 30: 1-11.

Omori M. 1973. Cultivation of marine copepods. Bulletin of Plankton Society of Japan 20(1): 3-11.

Perumal N.V., Rajkumar M., Perumal P., Rajasekar K.T. 2009. Seasonal variations of plankton diversity in the Kaduviyar Estuary, Nagapattinam, Southeast Coast of India. Journal Environmental Biology 30: 10351046.

Peterson W.T.P., Kiorboe T. 1991. Copepod egg production, molting and growth rates, and secondary production in the Skagerrak in August 1988. Journal of Plankton Research 13: $131-154$.

Rajthilak C., Santhanam P., Anusuya A., Pazhanimuthu A., Ramkumar R., Jeyaraj N., Perumal P. 2014. Laboratory culture and growth population of brackish water harpacticoid copepod, Niktora affinis (Gurney, 1927) under different temperatures, salinity and diets. World Journal of Fish and Marine Sciences 6(1): 72-81

Robinson, E.H., Li, M.H. 2007. Catfish protein nutrition. Tee Fish Site, Sustainable Marine Aquaculture, Online Courses From UMASS BOSTON.

https://thefishsite.com/articles/catfishprotein-nutrition

Sampey A., McKinnon A.D., Meekan M.G., McCormick M.I. 2007. Glimpse into guts: Overview of the feeding of larvae of tropical shorefishes. Marine Ecology Progress Series 339: 243-257.

Santhanam P., Perumal P. 2012 ${ }^{a}$. Effect of temperature, salinity and algal food concentration on population density, growth and survival of marine copepod Oithona rigida Giesbrecht. Indian Journal of Marine Science 41: 369-376.

Santhanam P., Perumal P. 2012 ${ }^{\text {b }}$. Evaluation of marine copepod Oithona rigida Giesbrecth as live feed for larviculture of Asian seabass Lates calcalifer Bloch with special reference to nutritional value. Indian Journal of Fisheries 59(2): 127-134.

Steffens W. 1989. [Principles of fish nutrition]. Hal Sted Press Advision of John Wiley and Son, New York, 384 pp.

Suminto, Chilmawati D., Harwanto D. 2018. The effect of fermented organic feed on the performance of Oithona sp. in semi-mass culture condition. Omni-Akuatika 14(3): 5359.

Suminto, Chilmawati D., Susilowati T., Adhinugroho I. 2019. The effects of microalgal diet with enrichment of fermentedorganic matters (tofu waste, rice bran and fish meal) ongrowth and reproduction of Diaphanosoma brachyurum. 4th International Conference on Tropical and Coastal Region Eco Development. IOP Conference Series: Earth and Environmental Science 246 (2019) 012036

Takahashi T., Uchiyama I. 2007. Morphology of the naupliar stages of some Oithona species (copepoda: cyclopoida) occurring in Toyama Bay, Southern Japan Sea. Plankton and Benthos Research 2(1): 12 - 27.

Wang M., O'Rorke R., Nodder S.D., Jeffs A.G. 2014. Nutritional composition of potential zooplankton prey of the spiny lobster phyllosoma (Jasus edeardsii). Marine and Freshwater Research 65: 337-349

Yebra L., Elisa B., Rodrigo A., Veronica P., Albert C., Enric S. 2011. Protein and nucleic acid metabolism as proxies for growth and fitness of Oithona davisae (Copepod, Cyclopioda) early developmental stages. Journal of Experimental Marine Biology and Ecology 406: 87-94

Zamora-Terol S., Swalethorp R., Kjellerup S., Saiz E., Nielsen T.G. 2014. Population dynamics and production of the small copepod Oithona sp. in a subarctic fjord of West Greenland. Polar Biology 37: 95 